\title{
Pemanfaatan Berbagai Limbah Padat Pabrik Kelapa Sawit Terhadap Pertumbuhan dan Hasil Tanaman Terung Gelatik (Solanum Melongena L.)
}

\author{
Nani Rohaeni ${ }^{1}$ \\ ${ }^{1}$ Staf Pengajar Program Studi Agroteknologi, Sekolah Tinggi Pertanian Kutai Timur \\ Jl. Soekarno-Hatta No. 1, Kab. Kutai Timur \\ email : nnrasid85@gmail.com
}

\section{ABSTRACT}

The aims of research are (1) identify the effects of oil palm solid waste on the growth and yield of eggplant (2) identify the type of fertilizer where gave the best effect on the growth and yield of eggplant. This research was conducted from November 2016 to February 2017, located in a garden test in Sangatta, East Kutai. This research used Randomize Block Design which 4 treatments and 6 replications, i.e: $\left(P_{0}\right)$ without fertilizer, $\left(P_{1}\right)$ solid, $\left(P_{2}\right)$ palm shellash, $\left(P_{3}\right)$ Fiber. The obtained data was analyzed by $F$ Test $1 \%$ and $5 \%$ and be continued with LSD at $5 \%$ if the treatment had significant effect.The results of the research showed that the best growth of plant height at 40 days after planting move, and the best branch growth at 60 days after planting move, and the best yield production result is 1.882 kilogram solid treatment.

Keywords: Eggplant, Oil Palm, Solid Waste

\section{ABSTRAK}

Tujuan penelitian adalah untuk : (1) Untuk mengetahui pengaruh pemberian pupuk limbah padat sawit terhadap pertumbuhan dan hasil tanaman terung, (2) Untuk mengetahui jenis pupuk yang memberikan pengaruh terbaik terhadap pertumbuhan dan hasil tanaman terung. Penelitian ini dilaksanakan pada Bulan November 2016 sampai Februari 2017, pada kebun percobaan di Sangatta Utara, Kabupaten Kutai Timur. Rancangan yang digunakan adalah Rancangan Acak Kelompok (RAK) yang terdiri atas 4 taraf perlakuan dan di ulang sebanyak 6 kali. Taraf perlakuan yaitu $\left(\mathrm{P}_{0}\right)$ Tanpa Pupuk, $\left(\mathrm{P}_{1}\right)$ Solid, $\left(\mathrm{P}_{2}\right)$ Abu Cangkang, $\left(\mathrm{P}_{3}\right)$ Fiber. Untuk mengetahui pengaruh perlakuan maka dianalisis dengan sidik ragam Uji $\mathrm{F} 5 \%$ dan $1 \%$ dan bila terdapat hasil berbeda nyata atau sangat nyata maka dilanjutkan dengan uji BNT 5\%. Hasil penelitian pertumbuhan terbaik pertumbuhan tinggi tanaman 40 HSPT dan pertumbuhan cabang tanaman terbaik pada umur 60 HSPT dan serta hasil produksi tanaman terung perpetak adalah perlakuan solid sebanyak $1,882 \mathrm{~kg}$.

Kata kunci : Limbah Padat, Sawit, Terung Gelatik.

\section{Pendahuluan}

\subsection{Latar Belakang}

Terung merupakan komoditas pertanian yang penting dan dibutuhkan masyarakat di Indonesia. Hal ini di sebabkan oleh terung mempunyai kadar gizi yang cukup tinggi cukup lengkap dan mempunyai nilai ekonomis tinggi. Adapun komposisi kimia terung per 100 gram yaitu air 92,70 gram, abu (mineral) 0,60 gram, beri 0,60 mg, karbohidrat 5,70 gram, lemak 0,20 gram,serat 0,80 gram, kalori 24,00 kal, fosfor $27,00 \mathrm{mg}$, kalium 223,00 $\mathrm{mg}$, protein 1,10 gram, natrium 4,00 mg; vitamin B3 0,60 mg; vitamin B2 0,05 mg, vitamin B1 10,00 mg,vitamin A 130,00 SI, dan vitamin C 5,00 mg Direktorat Gizi (Budiman, 2008).

Perkembangan budidaya tanaman terung di wilayah Kabupaten Kutai Timur masih belum begitu luas karena budidaya tanaman terung dipengaruhi oleh berbagai faktor, antara lain yaitu unsur hara, suhu, cahaya, dan tanah. Menurut Dinas Pertanian dan Badan Pusat Statistik Kutai Timur (2015), luas area tanam dan luas area panen tanaman 
terung di wilayah Kabupaten Kutai Timur pada tahun 2013 adalah 8.351 ha dan pada tahun 2014 luas area tanam dan panen menurun men jadi 1.349 ha.Usaha untuk meningkatkan kualitas pertumbuhan terung yang baik salah satunya yaitu dengan pemberian pupuk organik.

Budidaya tanaman terung secara organik memiliki prospek yang sangat menjanjikan. Pertanian organik menuntut agar lahan yang di gunakan tidak tercemar oleh bahan kimia mempunyai aksesibilitas yang baik dan kesinambungan. Pemberian pupuk organik kedalamtanah dapat mempengaruhi dan memperbaiki sifat - sifat tanah baik fisik, kimia maupun biologis tanah (Parnata, 2010) dalam Bukhari, 2013). Oleh karena itu pemberian pupuk organik dinilai sangat mendukung upaya meningkatkan produktivitas tanaman pertanian (Musnamar, 2003). Menurut Suriadikarta dan Setyorini (2012), pupuk organik dapat dibuat dari berbagai jenis bahan, antara lain sisa panen (jerami,brangkasan, tongkol jagung, bagas tebu, dan sabut kelapa), serbuk gergaji, kotoran hewan, limbah media jamur, limbah pasar, limbah rumah tangga, dan limbah pabrik.

Industri kelapa sawit merupakan salah satu industri yang berkembang pesat pada dua dekade terakhir dan diproyeksikan masih akan tetap menjadi salah satu primadona dalam subsektor perkebunan pada masa mendatang. Meskipun pertumbuhan kelapa sawit Indonesia cukup pesat, namun daya saing komoditas (competitive advantages) kelapa sawit (CPO) di pasar internasional masih lemah. Salah satu strategi kunci yang diyakini mampu meningkatkan daya saing adalah dengan perbaikan teknologi, baik pada tingkat on farm maupun off farm, termasuk juga yang berkaitan dengan pengelolaan limbah.

Limbah industri kelapa sawit adalah limbah yang dihasilkan pada saat proses pengolahan kelapa sawit. Limbah adalah kotoran atau buangan yang merupakan komponen pencemaran yang terdiri dari zat atau bahan yang tidak mempunyai kegunaan lagi bagi masyarakat. Limbah industri dapat digolongkan kedalam tiga golongan yaitu limbah cair, limbah padat, dan limbah gas yang dapat mencemari lingkungan. Limbah ini merupakan sumber pencemaran yang potensial bagi manusia dan lingkungan, sehingga pabrik dituntut untuk mengolah limbah melalui pendekatan teknologi pengolahan limbah (end of the pipe). Diantara upaya tersebut adalah pemanfaatan limbah padat sebagai pupuk organic untuk tanaman.

Limbah padat kelapa sawit (sludge) adalah benda padat yang mengendap di dasar bak pengendapan dalam sarana pengolahan limbah dan harus dibuang atau dikelola untuk mengurangi pencemaran lingkungan. Tetapi sludge yang dihasilkan dari Pengolahan Minyak Sawit (PMS) mengandung unsur hara nitrogen, fosfor, kalium, magnesium, dan kalsium yang cukup tinggi sehingga dapat digunakan sebagai pupuk. 
Abu cangkang kelapa sawit adalah abu yang telah mengalami proses penggilingan dari kerak pada proses pembakaran cangkang dan serat buah pada suhu $500-700{ }^{\circ} \mathrm{C}$ pada dapur tungku boiler yang dimanfaatkan untuk Pembangkit Listrik Tenaga Uap (PLTU), dari pembakaran tersebut diperoleh kerak boiler.

Fiber adalah limbah padat yang berbentuk seperti rambut, apabila telah mengalami proses pengolahan berwarna coklat muda, serabut ini terdapat dibagian kedua dari buah kelapa sawit setelah kulit buah kelapa sawit.didalam serabut dan daging buah sawitlah minyak CPO terkandung. Pemanfaatan macam - macam limbah padat pabrik sawit, sebagai pupuk dalam budidaya tanaman terong(Solanum melongena L) diharapkan dapat meminimalkan pencemaran lingkungan dan membuka lapangan pekerjaan sampingan.

\subsection{Rumusan Masalah}

Rumusan masalah pada penelitian ini adalah:

1) Bagaimana pengaruh pertumbuhan dan hasil terung (Solanum melongena $L$ ) dengan menggunakan macam - macam limbah padat pabrik kelapa sawit ?

2) Jenis pupuk limbah yang mana yang memberikan pengaruh tanaman terung?

\subsection{Tujuan Penelitian}

Tujuan penelitian adalah:

1) Untuk mengetahuai pengaruh pemberian pupuk padat limbah pabrik kelapa sawit terhadap pertumbuhan dan hasil tanaman terung.

2) Untuk mengetahui jenis pupuk padat limbah kelapa sawit terbaik yang memberikan pengaruh pertumbuhan dan hasil pada tanaman terung gelatik.

\subsection{Manfaat Penelitian}

Manfaat dari penelitian ini adalah :

1) Memanfaatkan limbah untuk pupuk dalam budidaya tanaman terung

2) Memberikan informasi kepada petani/dinas terkait akan manfaat limbah pada pabrik sawit untuk dimanfaatkan sebagai pupuk tanaman.

\section{Metode Penelitian}

\subsection{Waktu dan Tempat}

Penelitian ini dilaksanakan selama 3 bulan dimulai dari Bulan November 2016 sampai dengan Februari 2017, bertempat di kebun percobaan Jl. Soekarno Hatta Kec. Sangatta Utara Kabupaten Kutai Timur, Kalimantan Timur.

\subsection{Alat dan Bahan}

Bahan yang digunakan dalam penelitian ini meliputi : bibit terung Varietas Gelatik F1, solid, abu cangkang dan fiber. Sedangkan alat yang digunakan yakni, cangkul, parang babat, polybag, meteran,kalkulator, alat tulis dan alat dokumentasi. 


\subsection{Rancangan Penelitian}

Penelitian ini dirancang dengan Rancangan Acak Kelompok (RAK) yang terdiri dari 4 taraf perlakuan pemberian pupuk organik limbah pabrik kelapa sawit. Masing masing perlakuan di ulang sebanyak 6 kali sehingga terdapat 24 petak penelitian. Adapun perlakuan pupuk dalam penelitian ini adalah sebagai berikut :

PO = Tanpa pupuk

$\mathrm{P} 1=$ Dried decanter solid 375 gram/tanaman

P2 = Abu cangkang 375 gram/tanaman

P3 = Fiber 375 gram/tanaman

\subsection{Pelaksanaan Penelitian}

\subsubsection{Persiapan Lahan}

Lahan yang akan digunakan untuk penelitian terlebih dahulu dibersihkan dari gulma dan akar-akar tanaman maupun pepohonan dengan menggunakan parang. Setelah lahan dibersihkan, dilakukan pemasangan naungan dengan menggunakan paranet pada tempat pembibitan untuk mengurangi cahaya matahari yang dapat mempercepat penguapan. Selanjutnya pengukuran dan pembuatan bedengan $2 \times 2 \mathrm{~m}$.

\subsubsection{Penyemaian terung}

Biji terung yang ditanam berasal dari benih hibrida sehingga hasil yang dicapai lebih optimal. Ketika melakukan pemeraman benih terung dengan kertas atau handuk basah atau lembab selama 24 jam, media semai disiapkan.

\subsubsection{Penanaman terung}

Benih yang telah disemai selama 25 Hari Setelah Semai (HSS) dapat ditanam pada lubang tanam yang telah disediakan. Ciri dari bibit tanaman terung yang siap tanam adalah munculnya atau keluar 3 lembar helai daun sempurna. Penanaman dilakukan pada sore hari setelah dilakukan penggenangan untuk mempermudah pemindahan dan masa adaptasi pertumbuhan awal. Sistem tanam yang digunakan untuk terung adalah sistem baris tunggal (single row), dengan jarak antara tanaman $60 \mathrm{~cm} \times 60 \mathrm{~cm}$. Bibit yang siap tanam dimasukkan ke dalam lubang tanam yang telah dibuat sedalam $10-15 \mathrm{~cm}$ kemudian ditekan ke bawah sambil ditimbun dengan tanah yang berada di sekitar lubang.

\subsubsection{Pengaplikasian pupuk limbah pabrik kelapa sawit}

Pengaplikasian pupuk limbah limbah sawit sebanyak 375 gram pertanaman yang diberikan satu bulan sebelum penanaman pada lubang tanam.

\subsubsection{PemeliharaanTanaman}

a. Penyiraman

Penyiraman dilakukan pada pagi atau sore hari atau disesuaikan dengan kondisi tanah dan cuaca di lapangan.

b. Penyulaman 
Dilakukan apabila ada tanaman yang tidak tumbuh atau mati. Penyulaman dilakukan pada waktu 7 hari setelah tanam.

c. Penyiangan Gulma

Penyiangan dilakukan seminggu sekali sampai akhir panen terakhir dengan cara membersihkan atau mencabut gulma yang tumbuh di sekitar tanaman.

d. Pengendalian hama

Pengendalian hama dilakukan pengendalian secara mekanis, namun apabila tingkat serangan sedang atau tinggi, maka dilakukan pengendalian secara kimiawi.

\subsubsection{Panen}

Pemanenan dilakukan pada saat buah terung telah berukuran maksimal dan masih muda. Waktu yang tepat untuk panen terung adalah pagi atau sore hari pada keadaan cuaca cerah. Pada panen pertama kali dapat dipetik bila tanaman terung telah berumul tiga sampai empat bulan sejak tanam, untuk seterusnya tanaman terung dapat dipanen terus menerus hingga batas panen yang ke lima dengan selang waktu tiga hari sekali.

\subsection{Prosedur pengambilan data}

Adapun variabel yang diamati dalam penelitian ini antara lain:

a. Tinggi Tanaman

Tinggi tanaman diukur pada saat tanaman berumur 20, 40 dan 60 HSPT, yang diukur dari permukaan tanah sampai ke titik tumbuh tertinggi.

b. Jumlah Cabang Jumlah cabang dihitung pada saat tanaman telah berumur 20, 40 dan 60 HSPT.

c. Umur tanaman saat berbunga $80 \%$ (hari)

Umur berbunga dicatat saat tanaman telah berbunga dalam 1 petak telah berbunga.

d. Berat buah perpetak $(\mathrm{kg})$

Produksi dihitung dengan menimbang berat buah yang dihasilkan oleh tanaman sampel dari seluruh petak penelitian.

\subsection{Analisis Data}

Data dianalisis dengan Analisis Sidik Ragam berdasarkan uji F 5\% dan1 \%.Jika hasil sidik ragam menunjukkan pengaruh nyata, maka dilanjutkan dengan Uji BNT 5\%.

\section{Hasil dan Pembahasan}

\subsection{Tinggi Tanaman Terung( $\mathrm{Cm}$ )}

\subsubsection{Tinggi Tanaman Umur 20 Hari Setelah Pindah Tanam ( HSPT )}

Hasil analisis sidik ragam uji berbagai macam limbah padat pabrik kelapa sawit berpengaruh berbeda nyata atau sangat nyata terhadap rata - rata tinggi tanaman terung 
umur 20 HTPS. Hasil penelitian pemanfaatan berbagai macam limbah padat pabrik kelapa sawit terhadap rata-rata tinggi tanaman terung umur 20 HST tertera pada Tabel 1.

Tabel 1. Rata-rata tinggi tanaman terung umur $20 \mathrm{HSPT}(\mathrm{cm})$.

\begin{tabular}{cc}
\hline Perlakuan & Tinggi Tanaman Umur 20 HSPT (cm) \\
\hline p0 & $12,13 \mathrm{a}$ \\
p1 & $16,81 \mathrm{~b}$ \\
p2 & $15,69 \mathrm{~b}$ \\
p3 & $14,99 \mathrm{~b}$ \\
\hline
\end{tabular}

Keterangan: Angka rata - rata di ikuti oleh huruf yang sama berarti berbeda nyata berdasarkan Uji BNT 5\% $(2,67)$

Hasil uji BNT 5\% menunjukkan p1, p2 dan p3 memberikan pengaruh nyata pada parameter tinggi tanaman, hal ini di duga karena ke tiga perlakuan memiliki jumlah kandungan $\mathrm{N}$ yang mampu di serap oleh tanaman. Kandungan unsur $\mathrm{N}$ adalah : solid $3,52 \%$, abu cangkang $0,05 \%$ dan fiber $0,04 \%$. Hasil penelitian limbah padat pabrik kelapa sawit ini menunjukkan bahwa pemberian berbagai dosis pupuk limbah padat pabrik kelapa sawit menghasilkan tanaman yang lebih tinggi dibandingkan dengan tanpa pupuk organik. Seperti dikemukakan oleh Prihmantoro (1999) bahwa unsur hara N diperlukan tanaman untuk pertumbuhan vegetatif tanaman terutama batang, cabang dan daun.

Unsur nitrogen merupakan unsur hara yang berfungsi merangsang perkembangan dan pertumbuhan vegetatif tanaman. Hakim $d k k$.(1986) menyatakan bahwa, unsur nitrogen berperan dalam pembentukan sel-sel klorofil dimana klorofil berguna dalam fotosintesis sehingga dibentuk energi yang diperlukan sel untuk aktivitas pembelahan, pembesaran dan pertumbuhan tinggi.

\subsubsection{Tinggi Tanaman Umur 40 Hari Setelah Pindah Tanam ( HSPT )}

Hasil perhitungan sidik ragam uji berbagai macam limbah padat kelapa sawit berbeda nyata terhadap rata-rata tinggi tanaman terung umur 40 HSPT. Hasil penelitian uji berbagai macam limbah padat pabrik kelapa sawit terhadap rata-rata tinggi tanaman terung 40 HSPT tertera pada Tabel 2.

Tabel 2 : Rata-rata tinggi tanaman terung umur $40 \mathrm{HSPT}(\mathrm{cm})$.

\begin{tabular}{cc}
\hline Perlakuan & Tinggi Tanaman Umur 40 HSPT \\
\hline p0 & $37,10 \mathrm{a}$ \\
p1 & $46,18 \mathrm{~b}$ \\
p2 & $41,61 \mathrm{ab}$ \\
p3 & $40,51 \mathrm{ab}$ \\
\hline
\end{tabular}

Keterangan : Angka rata - rata di ikuti oleh huruf yang sama berarti berbeda nyata berdasarkan Uji BNT 5\% (5,84)

Hasil uji nilai BNT 5\% menunjukkan p1, p2 dan p3 memberikan pengaruh nyata pada parameter tinggi tanaman, hal ini disebabkan karena unsur nitrogen $(\mathrm{N})$ yang sangat dibutuhkan untuk pertumbuhan vegetatif tanaman tersedia masih tersedia di dalam tanah. 


\subsubsection{Tinggi Tanaman Umur 60 Hari Setelah Pindah Tanam ( HSPT )}

Berdasarkan hasil perhitungan sidik ragam uji berbagai macam limbah padat kelapa sawit berbeda tidak nyata terhadap rata-rata tinggi tanaman terung umur 60 HSPT. Hasil penelitian respon uji berbagai macam limbah padat kelapa sawit berbeda tidak nyata terhadap rata-rata tinggi tanaman terung umur 60 HSPT tertera pada Tabel 3.

Tabel 3. Rata-rata tinggi tanaman terung umur $60 \mathrm{HSPT}(\mathrm{cm})$.

\begin{tabular}{cc}
\hline Perlakuan & Tinggi Tanaman Umur 60 HSPT (cm) \\
\hline p0 & 61,67 \\
p1 & 65,06 \\
p2 & 63,31 \\
p3 & 63,78 \\
\hline
\end{tabular}

Hasil penelitian rata - rata tinggi tanaman pada perlakuan uji limbah padat pabrik kelapa sawit, menunjukan tidak berbeda nyata. Hal ini diduga tanaman terung pada umur 60 hstp telah memasuki fase generatif. Fase generatif adalah masa dimana tanaman mempunyai kemampuan untuk tetap tumbuh meskipun sudah tidak terlihat pertumbuhan yang signifikan. Hal ini didasarkan dengan pendapat Widayat dan Purba (2015), jika unsur - unsur utama yang dibutuhkan pada awal pertumbuhan sudah tercukupi maka tidak terlihat perbedaan yang nyata.

\subsection{Jumlah Cabang Tanaman Terung}

\subsubsection{Jumlah Cabang Tanaman Umur 20 Hari Setelah Pindah Tanam(HSPT)}

Berdasarkan hasil perhitungan sidik ragam menunjukan uji berbagai pupuk padat limbah pabrik kelapa sawit berpengaruh tidak nyata terhadap rata - rata jumlah cabang tanaman terung 20 HSPT. Hasil penelitian uji berbagai macam limbah padat pabrik kelapa sawit rata-rata jumlah cabang tanam terung umur 20 HSPT tertera pada Tabel 4.

Tabel 4.Cabang tanaman terung umur 20 HSPT.

\begin{tabular}{cc}
\hline Perlakuan & Jumlah Cabang Tanaman Umur 20 HSPT \\
\hline p0 & 1,33 \\
p1 & 2,88 \\
p2 & 3,13 \\
p3 & 2,00 \\
\hline
\end{tabular}

Hasil analisis sidik ragam menunjukkan bahwa rata - rata jumlah cabang pada umur 20 HSPT tidak berbeda nyata. Hal ini diduga karena tanaman terung masih muda, belum memiliki perakaran yang sempurna dalam menyerap unsur hara serta adanya kondisi tanah dalam perlakuan yang diberikan belum merangsang tumbuhnya morfologi cabang, hal ini juga dipengaruhi sifat internal dari tanaman itu sendiri.

Sebagaimana pendapat Jumin (2005), yang menyatakan bahwa selain faktor luar (lingkungan), pertumbuhan tanaman juga dipengaruhi oleh faktor yang ada didalam 
tanaman itu sendiri. Pendapat tersebut diperkuat oleh Lakitan (2004) yang menyatakan bahwa pada awal pertumbuhan tanaman, kandungan unsur hara belum terserap oleh tanaman, selain itu pada fase vegetatif tanaman dipengaruhi oleh sifat internal tanaman itu sendiri sehingga pengaruh dari luar faktor tanaman tidak terlalu berpengaruh terhadap panjang tanaman

\subsubsection{Jumlah Cabang Tanaman Umur 40 Hari Setelah Pindah Tanam(HSPT)}

Hasil perhitungan sidik ragam menunjukan respon uji berbagai pupuk padat limbah pabrik kelapa sawit, perlakuan berpengaruh tidak nyata terhadap rata - rata jumlah cabang tanaman kacang panjang umur 40 HPST. Hasil penelitian respon waktu penyiangan dan pengolahan tanah terhadap rata-rata jumlah cabang tanaman terung umur 40 HSPT tertera pada Tabel 5.

Tabel 5 : Cabang tanaman terung umur 40 HSPT.

\begin{tabular}{cc}
\hline Perlakuan & Jumlah Cabang Tanaman Umur 40 HSPT \\
\hline p0 & 12,92 \\
p1 & 15,36 \\
p2 & 13,93 \\
p3 & 15,33 \\
\hline
\end{tabular}

Hasil sidik ragam rata - rata jumlah cabang pada umur 40 HSPT pada perlakuan uji berbagai pupuk padat limbah pabrik kelapa sawit menunjukan tidak berbeda nyata. Hal ini diduga karena dengan kondisi tanah dalam perlakuan yang diberikan belum merangsang tumbuhnya morfologi cabang oleh tanaman dan tanaman cenderung mengalami pertambahan tinggi sehingga masih terbatasi keluarnya cabang. Hal ini sesuai dengan pendapat Madyoharsono (1982), yang menyatakan pertumbuhan tanaman cenderung untuk mempertinggi batang ke atas serta memperpanjang buku, sebagai usaha untuk bersaing mendapat sinar matahari. Kesempatan tanaman untuk memperbanyak cabang dan daun menjadi berkurang.

Bila persaingan tanaman dalam memanfaatkan faktor tumbuh yang tersedia lebih besar, kemampuan tanaman untuk membentuk cabang berkurang karena energi matahari yang diserap oleh tanaman lebih sedikit. Hal ini dinyatakan juga oleh Leopold dan Kriedemann (1983), bahwa pada populasi yang tinggi tanaman terjadi persaingan cahaya dan naungan pada daun yang berdekatan, sehingga cahaya yang sampai di bagian bawah makin sedikit yang akan mengganggu pertumbuhan tanaman untuk membentuk cabang berkurang.

\subsubsection{Jumlah Cabang Tanaman Umur 60 Hari Setelah Pindah Tanam(HSPT)}

Hasil analisis sidik ragam menunjukkan bahwa respon uji berbagai pupuk padat limbah pabrik kelapa sawit perlakuan berpengaruh tidak nyata terhadap rata - rata jumlah cabang tanaman terung umur 60 HSPT. Hasil penelitian uji berbagai pupuk padat limbah 
pabrik kelapa sawit terhadap rata-rata jumlah cabang tanaman terung umur 60 HSPT tertera pada Tabel 6.

Tabel 6 : Cabang tanaman terung umur 60 HST.

\begin{tabular}{lc}
\hline \multicolumn{1}{c}{ Perlakuan } & Jumlah Cabang Tanaman Umur 60 HSPT \\
\hline P0 (tanpa perlakunaan) & $20,27 \mathrm{a}$ \\
P1 (solid) & $23,05 \mathrm{~b}$ \\
P2 (abu cangkang) & $21,52 \mathrm{a}$ \\
P3 (fiber) & $25,12 \mathrm{~b}$
\end{tabular}

$\overline{\text { Keterangan : Angka rata - rata di ikuti oleh huruf yang sam berarti berbeda nyata berdasarkan }}$ Uji BNT 5\% $(3,30)$

Hasil pengamatan jumlah cabang pada umur 60 HSPT menunjukan berbeda nyata. Hal ini diduga karena tanaman telah mencapai tinggi yang maksimal, sehingga berdampak pada terdistribusinya unsur hara untukpembentukan cabang yang bersumber dari solit dan fiber dan ditunjang oleh penyerapan unsur hara yang semakin baik. Hal ini sesuai dengan pendapat Yulistrarini (1991) dalam Djunaedy (2009) yang menyatakan bahwa tanaman menyerap unsur hara dalam jumlah yang sedikit, sejalan dengan umur tanaman, kecepatan penyerapan unsur hara tanaman akan meningkat jika umur bertambah sesuai siklus hidupnya. Adapaun kualitas hidup tanaman juga sangat bergantung pada ketercukupan hara dan kondisi lingkungannya serta kemampuan akar tanaman dalam menyerap unsur hara.

Pada umur 60 HSTP, biasanya pupuk organik yang diberikan sudah dekomposisi dengan baik. Seperti dikemukakan oleh Musnamar (2003) bahwa pupuk organik memiliki sifat lambat menyediakan unsur hara bagi tanaman karena memerlukan waktu untuk proses dekomposisinya (slow release).

\subsection{Umur Berbunga ( Hari )}

Berdasarkan hasil perhitungan sidik ragam menunjukan respon uji berbagai pupuk padat limbah pabrik kelapa sawit berpengaruh tidak nyata terhadap rata - rata umur berbunga tanaman terung (Tabel 7).

Tabel 7 : Hasil penelitian respon respon uji berbagai pupuk padat limbah pabrik kelapa sawit terhadap rata-rata umur berbunga tanaman terung ( Hari )

\begin{tabular}{cc}
\hline Perlakuan & Umur berbunga 80\% (hari) \\
\hline p0 & 34,83 \\
p1 & 33,17 \\
p2 & 34,33 \\
p3 & 34,17 \\
\hline
\end{tabular}

Tidak adanya pengaruh nyata terhadap respon ini, diduga karena limbah padat pabrik kelapa sawit yang diberikan tidak mencukupi kebutuhan unsur fosfor yang dibutuhkan oleh tanaman terung terutama pada saat memasuki fase generatif. Hal inilah yang menyebabkan dari setiap perlakuan yang diberikan tidak menunjukan perbedaan 
umur berbunga yang signifikan. Hal ini sesuai dengan pendapat Sitrianingsih (2010), yang menyatakan bahwa untuk memenuhi kebutuhan tanaman, kita harus bisa menyediakan unsur hara $\mathrm{P}$ yang terdapat pada dosis pupuk organik yang diberikan dalam jumlah/dosis yang diperkirakan cukup seimbang pada masa vegetatif dan terus berlangsung sampai masa generatif yang diawali dengan pembentukan bunga dan pengisian buah.

\subsection{Berat Buah Perpetak (kg)}

Hasil analisis sidik ragam menunjukan respon respon uji berbagai pupuk padat limbah pabrik kelapa sawit perlakuan berpengaruh tidak nyata terhadap rata - rata berat buah perpetak tanaman terung. Hasil penelitian respon uji berbagai pupuk padat limbah pabrik kelapa sawit terhadap rata-rata umur berat buah perpetak tanaman terung tertera pada Tabel 8.

Tabel 8: Berat buah perpetak $(\mathrm{kg})$

\begin{tabular}{cc}
\hline Perlakuan & Berat Buah Perpetak (kg) \\
\hline p0 & 1,496 \\
p1 & 1,882 \\
p2 & 1,809 \\
p3 & 1,802 \\
\hline
\end{tabular}

Hasil sidik ragam rata-rata berat buah perpetak $(\mathrm{kg})$ pada perlakuan uji berbagai limpah padat pabrik kelapa sawit tidak berbeda nyata. Hal ini diduga karena tidak tersedianya unsur fosfat dalam tanah, hal sesuai dengan pendapat Kartasapoetra dan Sutedja (2005) yang menyatakan bahwa dengan tersedianya hara fosfat maka dapat mempercepat pembungaan dan pemasakan buah, biji atau gabah serta dapat meningkatkan produksi biji-bijian.Unsur $P$ yang merupakan salah satu unsur yang fungsinya memperbesar persentase terbentuknya bunga menjadi buah dan biji (Hartatik, 2003).

Selain unsur $\mathrm{P}$ unsur $\mathrm{K}$ sangat dibutuhkan oleh tanaman terung untuk memperoleh produksi yang tinggi. Malezieux dan Bartholomew (2003) mengemukakan bahwa, kalium dibutuhkan dalam jumlah yang banyak untuk mendukung pertumbuhan tanaman terung. Kekurangan kalium akan mengurangi produksi fotosintesis dan selanjutnya pertumbuhan tanaman, berat buah dan tunasbuah (Kelly 1993). Kekurangan kalium juga menyebabkan buah yang dihasilkan mempunyai kandungan gula dan asam yang rendah dan berwarna pucat (Py et al., 1987). Elumalai et al. (2002) mengemukakan bahwa kalium diperlukan untuk akumulasi dan translokasi karbonat yang baru saja dibentuk tanaman dari hasil fotosintesis. Selain itu, ion $\mathrm{K}^{+}$memfasilitasi beberapa respon fisiologi pada tanaman, termasuk pembukaan dan penutupan stomata, gerakan daun dan regulasi polarisasi membran. Kalium merupakan pengaktif dari sejumlah besar enzim penting untuk 
fotosintesis dan respirasi, juga mengaktifkan enzim yang diperlukan untuk pembentukan pati dan protein (Marschner, 1995).

\section{Kesimpulan}

Kesimpulan dari penelitian adalah pemberian berbagai macam pupuk padat limbah kelapa sawit berpengaruh nyata pada parameter tinggi tanam 20, 40 HSPT dan parameter cabang tanaman pada $60 \mathrm{HSPT}$, tidak berpengaruh pada parameter tinggi tanaman 60 HSPT, jumlah cabang tanaman umuur 20 dan 40 HSPT, 80\% umur berbunga, dan berat tanaman perpetak. Hasil pertumbuhan vegetatif tanaman terung terbaik ditunjukan pada perlakuan pupuk padat limbah padat jenis solid dengan dosis 375 gram/tanaman adalah $1,882 \mathrm{~kg}$.

\section{Daftar Pustaka}

Badan Pusat Statistik Kutai Timur 2015, Sangatta Utara dalam Angka, Siswa. Kutai Timur Bukhari. 2013."Sains Riset". Pengaruh Pemberian Pupuk Organik Dan Air Cucian Beras Terhadap Pertumbuhan Dan Hasil Tanaman Terung (Solanum Melongena L.) (3):1.( http://eprints.ums.ac.id/43354/22/DAFTAR\%20PUSTAKA.pdf)

Djunaedy A. 2009. Biopestisida sebagai Pengendali Organisme Pengganggu Tanaman (OPT) yang Ramah Lingkungan, Unijoyo. Embryo. Vol. 6.No(http://repository.usu.ac.id/bitstream/handle

Elumalai et al. 2002. Amutation in the Arabidopsis Kt2/Kup2 potassium transporter gene affects shoot cell expansion. Plant Cell, 14: 119-131.

Harsono. M. 1982. Pembibitan cacao. Balai Penelitian dan Perkembangan Pertanian. Departemen Pertanian (http://eprints.umk.ac.id Hartatik, W. 2003. Tithonia diversifolia Sumber Pupuk Hijau. Warta Penelitian dan Pengembangan Pertanian Vol.29, No.5,

Jumin, H.B. 2005. Dasar-dasar Agronomi (AGRON). Jakarta: PT Raja Grafindo Persada http://staff.unila.ac.id/bungdarwin/?page_id=245.

Kartasapoetra AG. dan Sutedjo. 2005. Pengantar IImu Tanah. Penerbit Rineka Cipta. Jakarta. ( http://repository.usu.ac.id/bitstream/handle/

Kelly DS. 1993. Nutritional disorders. Didalam: Broadley RH, Wasman III RC, and Sinclair EC . Editor. Pineapple Pests and Disordes. Australia. Queensland Dept. of Primary Industries. HIm $33-42$.

Lakitan, Benyamin. 2004. Dasar-Dasar Fisiologi Tumbuhan. Jakarta. Raja Grafindo Persada

Leopold, A. C. and P. E. Kriedemann. 1983. Plant growth and Development. Tata McGraw-Hill Publ.Co.Ltd. New Delhi. p: 115340.(http://etd.repository.ugm.ac.idpotongan/S1-2014-269725-bibliography.pdf

Musnamar, E.I. 2003. Pupuk Organik Cair dan Padat, Pembuatan, Aplikasi. Penebar Swadaya, Jakarta.

Malezieux E and Bartholomew DP. 2003. Plant Nutrition. di dalam: Bartholomew DP, Paul RE and Rohrbach KG. Edited. The Pineapple Botany, Production and Uses. USA. New York. CABI Pulising. HIm. 143-166. 
Marschner, H. 1995. Mineral Nutrition of Higher Plants, dalam Pengaruh Cendawan Mikoriza Arbuskula dan Naungan Terhadap Pertumbuhan Bibit Kayu Manis (Cinnamomum burmanii BL.), Delvian. 2006. Peronema Forestry Science Journal. 2 : 10-15. Musnamar. 2003. Pengaruh Pemberian Bahan Organik Terhadap SifatSifat Tanah Jurnal IImu Tanah dan Lingkungan.http://repository.usu.ac.id/bitstream/handle/123456789/29464/Referen ce.pdf;jsessionid=6FE6CAB6E11F0C41BA78A9D9C7F335DF?sequence $=2$

Primantoro, Heru. 1999. Memupuk Tanaman Sayur. Niaga Swadaya. Jakarta.

Py et al., 1987. The Pineapple, Cultivation and Uses. Editions G.-P. Maisonneuve, Paris. Sitrianingsih. 2010. Analisis Sensoris Untuk Industri Pangan dan Agro. IPB Press. Bogor.(eprints.unsri.ac.id/2703/1/Makalah_seminar_di_FP-UNS)

Sarief, S. 1986. Ilmu Tanah Pertanian. Pustaka Buana. Bandung.http://chylenzobryn.blogspot.co.id/2011/05/behaviorurldefaultvmlo.html.

Suriadikarta, D. A., \& Setyorini, D, 2005, Baku mutu pupuk organik. In D. A.

Widayat dan Purba 2015 Produktivitas tanaman dan kehilangan hasil tanaman padi (Oryza sativa L.) kultivar Ciherang pada kombinasi jarak tanam dengan frekuensi penyiangan berbeda jurnal.unpad.ac.id/kultivasi 